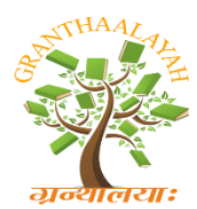
\author{
GRANTHAALAYAH \\ A knowledge Repository
}

INTERNATIONAL JOURNAL OF RESEARCH -

Science

\title{
PRESERVING BIODIVERSITY AND AGROECOSYSTEM OF COCOA CROPS
}

\author{
Ni Gst. Ag. Gde Eka Martiningsih ${ }^{1}$, I Made Suryana ${ }^{2}$, Cok Javandira ${ }^{2}$, Yohanes Leu ${ }^{2}$ \\ ${ }^{1,2}$ Lecturer at the Faculty of Agriculture Mahasaraswati Denpasar University, India
}

\begin{abstract}
Agroecosystem in cocoa plant was once of the important thing that have to manage intend to make the cacao plantation sustain. Cocoa was the mascot of industrial plant trade in Bali Province including in Tabanan Regency. Cocoa cultivation is almost done by most plantation farmers in Bali. The Bali Government, through the Tabanan Food and Agriculture Office, strongly supports the spread of cocoa cultivation. In 2010, a free seedling assistance policy for farmers was issued in order to obtain uniformity of growth and yield of cocoa plants. The types of cocoa cultivated by farmers vary, so that since 2015 there have been stunting and of cocoa pod rot (CPB). Several studies on cocoa have been carried out, but they have not been able to provide solutions to disease attacks, especially cocoa pod rot. In this regard, this study was conducted to provide solutions in terms of cocoa crop management in order to know how to reduce the percentage of damage to cocoa plants and determine the strategies to manage the Cocoa plant in field. This research shows that the best strategy to reduce the pod rot in cocoa plant is pruning the branch of cocoa. The pruning activity is useful to make the area of cocoa plant well maintained and clean.
\end{abstract}

Keywords: Cocoa; Strategy; Sanitation; Pruning; Yield.

Cite This Article: Ni Gst. Ag. Gde Eka Martiningsih, I Made Suryana, Cok Javandira, and Yohanes Leu. (2020). "PRESERVING BIODIVERSITY AND AGROECOSYSTEM OF COCOA CROPS." International Journal of Research - Granthaalayah, 8(1), 48-52. https://doi.org/10.29121/granthaalayah.v8.i1.2020.246.

\section{Introduction}

Indonesia has many vast islands and has very large potential land to develop cocoa as one of the plantation crops and is an important export potential of Indonesia which has world potential (Widnyana, et al. 2019). But according to (Hafsa et al, 2015) cocoa productivity in Indonesia is still low, only reaching $200 \mathrm{~kg} / \mathrm{ha} /$ year, still far below the productivity potential, which is actually 2 tons ha / year. One factor is the still low production of cocoa in Indonesia due to disease attacks on cocoa plants. Increasing cocoa fruit production is not easy, because the obstacles faced often occur in the field. These problems are pest and disease disorders. Several types of diseases can be found in the cultivation of cocoa plants, but the most important and very widespread spread is fruit rot disease and stem cancer which is caused by the fungus Phytophthorapalmivora. One of 
the new diseases reported in Indonesia in early 2011 was a thread blight caused by the fungus Marasmius sp. known as horse-tail blight, (Matitaputty et al, 2014).

Horsetail blight is not considered an important disease in cocoa plants, but if farmers do not take good care of their gardens and do not immediately control it, the disease can spread and reduce production and can even cause the death of cocoa plants. Bali Province is one of the cocoaproducing regions in Indonesia, its development areas include Tabanan, Jembrana, Buleleng, Gianyar, Bangli, Karangasem, and Badung Regencies (Windasari and Budhi, 2013).In particular, has a very wide area and is very suitable in the cultivation of cocoa plants so that it produces very high yields, but has recently experienced a decline in cocoa production due to pest and disease attacks. Tabanan Regency, in particular, has recently experienced a decline in the production of cocoa, the problem which are the source of the cause is the attack of pests and diseases and also the lack maintain of the cocoa field. The disease which is becomes dominant is the fungus (P. palmivora) which causes fruit rot and stem cancer, and leaf blight (Marasmiussp.) (Widnyana et al.2019).

In order to solve this problem this research will identify the activities that can be maintained the sanitation of the cocoa plantation in Marga Tabanan. The results of this study are expected to be important information for cocoa farmers to find out the level of damage to cocoa crops and the most harmful types of diseases. Also, to give the best strategy to maintain the sanitation of cocoa field.

\section{Materials and Methods}

The study was conducted in Tabanan Regency, Marga District, DesaTua. Materials used in the study were cocoa pods, Cocoa trunks, Cocoa Leaves. In the research process using the tools as follows: Ruler, Notebooks, Pens, Cameras, carpet colors $1 \mathrm{~m}$ x $1 \mathrm{~m}$, Thermometers, Hydrometers and Plywood measuring $50 \mathrm{~cm} \times 60 \mathrm{~cm}$. The implementation of this research location survey aims to observe cocoa plantations belonging to farmer groups in the Old Village and at the same time interact with the owners of the cocoa plantations, to determine the time of observation at the plantations that are the research sites.

\section{Data Collection}

Implementation of observations for data collection starts from the population of cocoa plants and the level of damage to cocoa plants due to disease attacks, both fruit rot disease, stem cancer, and leaf blight (Matitaputty et al, 2014). With the following data collection procedures:

- Create quetionaire for identify the strength, the weakness of cocoa plantation.

- Analysing with SWOT to get the quadrant of strategy.

- To create the best strategy for cocoa farmer to avoid the pod rot diseases attack.

\section{Results and Discussion}

\subsection{Biodiversity of Diseases}

Based on the result of research biodiversity of diseases found in the area of cocoa plants such as: 


\section{1) Cocoa rot (P. palmivora)}

Symptoms of fruit rot disease in cocoa are blackish-brown spots on the base, middle or tip of cocoa fruit. This disease attacks at all ages of fruit. Rotten fruit is black and hard. Symptoms of the disease are seen when observing at the location related to the opinion of Matitaputty et al (2014), which states that the disease is in the form of small spots on the fruit such as spots that are dirty and thick in parts of the fruit anywhere in each phase of fruit development, including seeds.

\section{2) Cancer of the stem (P. palmivora)}

The disease is easily recognized by symptoms of bulging of the stem or branches and blackish/dark, this part will rot and get wet, and discharge reddish fluid such as layers of rust. In the process of this research, I used a ruler as a tool to measure the distance between the surface of the land and cancer.

\section{3) Leaf blight (Marasmius sp.)}

The initial symptom shown by the fungus that causes this disease is a change in leaf color from green to yellow starting from the middle of the leaf following the leaf bones. Matitaputty et al (2014), the initial symptoms are characterized by a collection of white fungus threads (mycelium) that string the leaves and twigs. Furthermore, the threads turn brown and eventually turn black, the leaves dry and still hang on branches and some transparent leaves. In advanced symptoms, the leaves become dry and transparent and form clusters of dry leaves on the branches. The leaves did not fall to the ground but were stuck in twigs and hung so that a bunch of dried leaves appeared on the twigs.

Data collection was carried out to determine the diversity of diseases attack on cocoa plants. By observing and then recording the type and attack of disease in fruit, stems, and leaves, caused by P. palmivora and Marasmius sp. Data collection is carried out from one plant to another. This data collection is carried out to find out the plant population, the number of healthy fruit and fruit affected by the disease, population of stem cancer and many cocoa plants that have leaf blight. Further analysis conducted to create strategy for maintaining sanitation of field to preserve agro ecosystem of cocoa plant.

From the results of the SWOT analysis, in order to reduce the attack of paddy rot on cocoa plants in the village of Marga Tabanan is to empower cocoa farmers to always carry out cleaning around the garden and pruning productive branches continuously. Based on the strength (internal factors) of the cocoa petunia that the farmers are very experienced in cultivating cocoa. The marketing of cocoa products is definitely at a competitive price because it has cooperated with a local chocolate company. Although the weakness is that farmers often do not maintain the plants properly and sustainably.

\subsection{The Role of Farmer on Field Management}

The additional data to make plan for further research is how the role of farmer in field sanitation to maintain the sustainable cocoa plantation even on quantity or quality of production. This data observation is very important to create good agriculture practices on cacao plant. Furthermore, the community encouragement is very useful to increase participation and awareness of diseases invation and also early warning detection to reduce the attack of pest and diseases in cacao plantation especially in Marga Village. 


\section{Conclusions and Recommendations}

1) Fruit of Cocoa plants in Tabanan were attacked fruit rot disease (Phytophthorapamivora), stem cancer (P. pamivora), and leaf blight (Marasmiussp.). The average of fruit rot on cocoa plants in farmer group plantations was $71.17 \%$, where the highest was $82.85 \%$ (very heavy category) and the lowest in was $64 \%$ (weight category). The average of stem cancer in cocoa plants in farmer group estates is $1.62 \%$, where the highest is $2 \%$ (mild category) and the lowest in $0.96 \%$ (mild category). The average of blight disease in cocoa was $15.67 \%$, with the highest $2.38 \%$ (mild category) and the lowest $1.2 \%$ (mild category).

2) The most detrimental disease is fruit rot (P. palmivora) with an average $71.17 \%$ (weight category).

3) The strategy to manage sanitation in the field is encourage farmer community to participate in sanitation management.

The results of this study are expected to be important information for farmer groups in the Old Village in cultivating cocoa. Among them must maintain the cleanliness of the land that starts from pruning plants, cleaning weeds and spacing shade plants, because some of these factors can provide fungi (comfort for the proliferation of P. palmivora) and (Marasmiussp.) Which then continues to attack the fruit, stems and cocoa leaves, due to temperature and high humidity.

\section{Acknowledgements}

Great appreciation to Rector and Head of Research and Community Services of Universitas Mahasaraswati Denpasar for all support and very useful collaboration which is also funded this research through Universitas Mahasaraswati Denpasar's internal grant. The very befecial participation from Cocoa Farmer in Tabanan Regency where the data have already collected.

\section{References}

[1] Fausan A., L. Lubis and MI Piner. 2013. The Severity of Rot Cocoa Pod in Different Areas in Langkat Regency.Agrotechnology Online Journal. Vol. 3, No.3. It, 79- 84. (in Bahasa)

[2] Hafsa, S., Zuyasna and Firdaus. 2015. Screening of Cocoa Genotype Resistant to Fruit Disease (Phythophthra palmivora) in Aceh. Journal Floratek. 10:79-86. (in Bahasa)

[3] Matitaputty A., HRD Amanupunyo and W. Rumahlewang. 2014. Damage to Cocoa (Theobroma cacaoL) Due to an Important Illness in Taniwel District, in Seram Journal of agricultural cultivation. Vol. 10, No. 1, Hal, 6 - 9. (in Bahasa)

[4] Mertade, N. and Z. Basri. 2011. The Effect of Diameter of Leaf Stalks in Entres Against the Growth of Shoots Cocoa. Central Sulawesi R \& D Media. Vol: 4, No.1, 01 - 07. (in Bahasa)

[5] Motulo, HFJ, S. Sinaga., A. Hartana., G. Suantika and H. Aswidinnoor. 2007. Character and Morphology of Molecular Isolate of P. palmivora in Coconut and Cocoa. Littri Journal. Vol.3, No. 3, Hal, 111 - 118. (in Bahasa)

[6] Mulyaman, S. 2007. Methods of Observation Pest of Vegetable Plants. Directorate for Crop Protection Horticultural. Jakarta. Page, 6. (in Bahasa)

[7] Priyatno Edi. 2015. Pests and Diseases of The Cocoa Plant (Theobroma cacao L.). Extension Forestry in Bantul Regency.Vol: 3, No. 3, Hal, 7 - 10. (in Bahasa)

[8] Rosalie, D and D. Guest. 2008. Phytophthora palmivora Butler University of Sydney.

[9] Rubiyo and Siswanto. 2012. Increased Cocoa Production and Development in Indonesia. Ristri Bulletin. Vol: 3, No. 1, Hal, 33 - 41. (in Bahasa) 
[10] Sukanto, S. 2013. Disease Control. Self-Publisher Spreaders. Jakarta.Pg. 154 - 158. (in Bahasa)

[11] Suwarto, Y. Octavianty and S. Hermawati.2014. Top 15 Plantation Crops. Publisher SelfSpreaders., 48 - 52. Pages (in Bahasa)

[12] Widnyana, IK. Martiningsih,Ni Gst.Ag.Gde.,Javandira,C.,Suryana, IM., Yudiarini, Ni. 2019. Weeds Diversity and Its Impact on The Existence of Main Pests and Diseases in Theobroma Cacao in Tabanan District, Bali Indonesia Province

[13] Windasari, NPE and MKS Budi. 2013. Analysis of Intercropping on Farmer's Income in Impact Desa Munduk Temu,Regency Tabanan. Journal of Economic Development of the UdayanaUniversityof.Vol:2(5), page254-259. (inBahasa)

*Corresponding author.

E-mail address: ekamartini @gmail.com/ekamartini @unmas.ac.id 